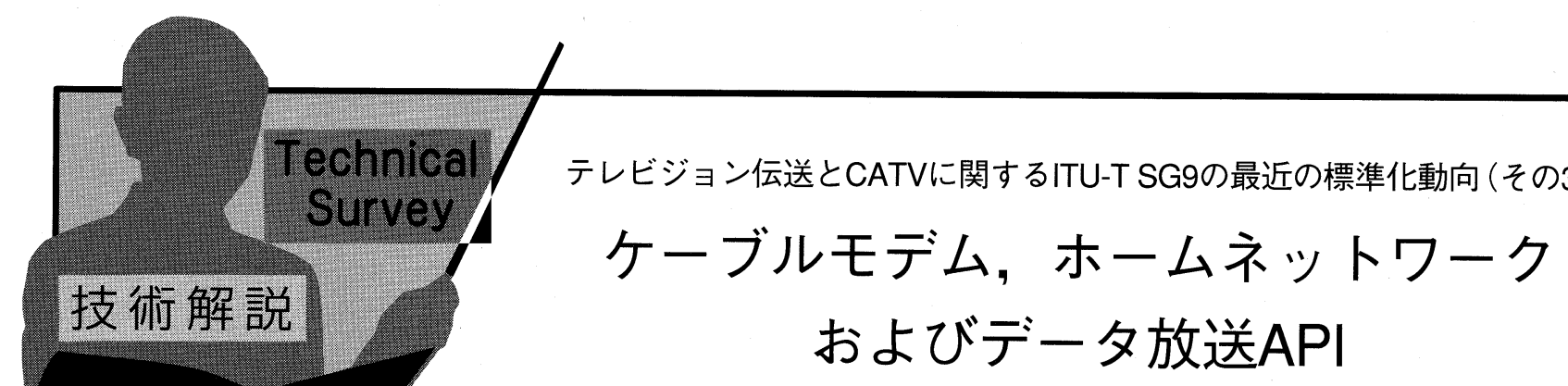

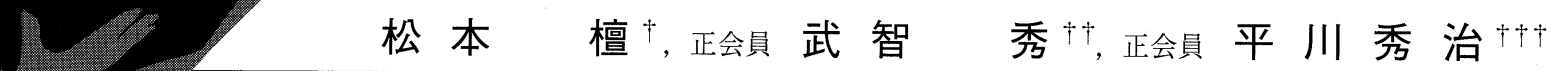

ITU-T SG9では統合型広域ケーブルネットワークおよび映像・音声伝送を研究対象としている. 本 技術解説ではSG9の所掌の中で, ケーブルモデム, ホームネットワークとデータ放送APIを記述して いる. ケーブルモデムについてはQOS制御の概要と次世代モデムの特徴が挙げられており, ホームネ ットワークではアーキテクチャとゲートウェイの概念が述べられている．またデー夕放送APIについ てはPE (Presentation Engine), EE (Execution Engine)の区別と特徵，国際標準化の経緯がまとめら れている.

\section{1. ケーブルモデム関連}

ケーブルネットワークのIP化の進展に伴ってケーブルモ デムは急速に進化を遂げてきた．初期の上り下り非対称型 に始まり，QoS制御を含む高速パケット転送技術の導入を 経て，ケーブルモデムは更なる高速化と雑音耐性を狙った 対称型に移行しつつある. 本章ではITU-T SG9で勧告化作 業が行われているケーブルモデム関連の技術動向について 解説する.

\subsection{QoS制御}

通信に先立ってコネクションを確立し，回線上で必要な 帯域を保証するギャランティ（保証）型回線ではQoS (Quality of Service) 制御はほとんど必要ないが, IPパケッ ト伝送のようにコネクションを予め設定しないべストエフ オート型回線ではQoS制御が重要となってくる，QoS制御 技術はレイヤによりさまざまな方式が提供されている．ア プリケーション層ではRTSP (Real Time Streaming Protocol), トランスポート層ではRTP (Real Time Transport Protocol), RTCP (RTP Control Protocol) や RSVP (Resource reSerVation Protocol)，ネットワーク層 ではTOS (Type of Service) やDiffServ等が使用される. 最 新のケーブルモデムのQoS機能としては以下が挙げられる. ミニスロットとはケーブルモデムが親機であるCMTS (Cable Modem Termination System)との間で同期をとる ための最小時間単位である。

†NECマグナスコミュニケーションス株式会社

††NHK 放送技術研究所

†††株式会社東芝 技術企画室 標準化グループ

"Recent ITU-T SG9 Standardization Activities Related to Television Transmission and CATV (3); Cable Modem, Home Network, Application Program Interface for Data and Multimedia Broadcasting" by Mayumi Matsumoto (NEC Magnus Communications Ltd., Tokyo), Masaru Takechi (NHK Science and Technology Reserch Laboratories, Tokyo) and Shuji Hirakawa (Toshiba Corporation, Corporate Standardization Group, Tokyo)
(1) UGS (Unsolicited Grant Service) : 固定ビットレート のパケットに対して固定のミニスロット数を割当て る方式で, 低遅延が要求される電話トラフィックに 向いている.

(2) rtPS (Real-Time Polling Service) : UGSに似ている が, CMTSはCMに対して周期的に上り信号送出のた めのミニスロット要求を受け付ける方式. 要求がな ければミニスロットを別要求に割当てるため, リソ ースの効率化が図れる.

(3) UGS/AD (Unsolicited Grant Service with Activity Detection）：上記二つを組合せたもので，常時は UGSとしておき，使用していないミニスロットは rtPSに振り向けられる.

(4) BE (Best Effort)：ミニスロットの割当て保証もなく, CMTS〜CM間で可能なときのみパケットを送受する 方式で, QoSは保証されない. 信頼度が低く高速性が 要求されるデー夕通信向き.

上記のパケット優先処理による QoS制御以外に, CATV 網全体でリアルタイム通信を行うためのメカニズムとして RSVPを使用するダイナミックQoSが最新ケーブルモデム で適用可能であるが, 解説は紙面の都合で割愛したい。

1.2 次世代ケーブルモデム

従来の非対称型ケーブルモデムでは，上りストリームの 変調方式が最速でも64QAMであったため, 伝送容量の増 加要求に応じることが難しくなってきている. 次世代ケー ブルモデムでは256QAMを導入し, 併せてリードソロモン 符号による誤り訂正機能を強化することでより高速, かつ 安定動作を保証できるようになる，具体的な上り方向での 特性改善点は以下の通りである.

(1) 高次シンボルレート : $5.12 \mathrm{Msymbol} / \mathrm{s}$ の採用

(2) 高次QAM変調方式：8QAM, 32QAM, 64QAM, 128QAM with TCMの追加

(3) S-CDMA 変調方式：128 直交拡散コードを使用 


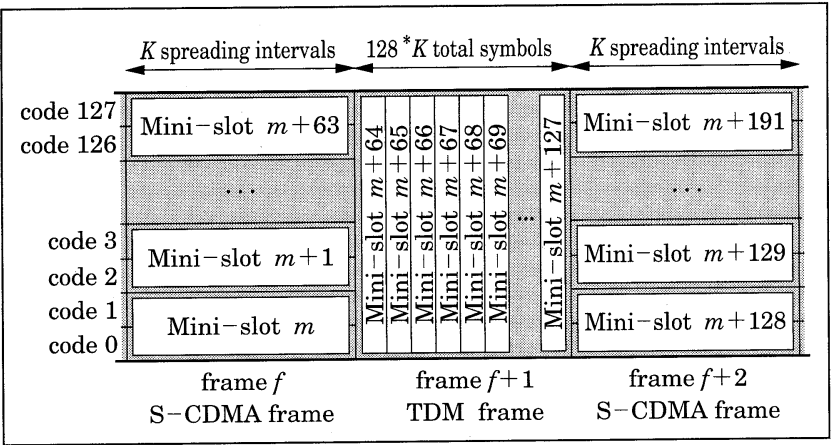

図 1 S-CDMACTDMA方式の併存
(4) 誤り訂正能力：トレリスコード変調とリードソロモ ン符号の併用で16シンボルまで訂正可能

（5）バースト雑音耐性：リードソロモンコードワードに よるインタリーブ強化

(6) マルチパス (反射) 抑圧 : 24 タップチャネル等化器の 採用

上記の中で，特記すべきはS-CDMA (Synchronized Code Division Multiple Access) 方式の採用である. 従来のケー ブルモデムはTDMA (Time Division Multiple Access) 方 式のみであり，遅延と高速性に優れているが，1ミニスロ ットでのケーブルモデム接続台数は1台のみしか許されて いなかった. S-CDMAにすれば同時接続可能なケーブルモ デムは最大で 64 台となり，大幅にスループットが改善され る. 両方式はケーブル網上で時分割で併存できるため, 従 来のケーブルモデムとの接続互換性が保たれている（図1).

S-CDMA方式は, (1) 直接シーケンス拡散スペクトルと直 交符号の集合を用いた複数アクセス変調技術であり雑音に 強い，(2) 直交性は伝送波形の配列と同期化により維持され るため正確な同期回路が必要となる, (3) 時間と符号領域を 同時に割当てることが可能，といった特徴が挙げられる.

\section{3 呼制御サーバ}

\section{〜加入者端末間のプロビジョニング仕様〜}

ケーブルモデムシステムの設定や保守のための仕様は， プロビジョニング仕様と呼ばれる. 現在のところ, プロビ ジョニング機能はCMTSが設置される局舎に個別に設置さ れることが多い。将来的には, WEBサービスモデルを用 いてこのプロビジョニング情報を共通サーバに格納して各 オペレータからの要求に応じることが考えられている. 呼 制御サーバ (CMS) とプロビジョニングサーバ間のサービ スプロビジョニング情報交換のためのインタフェースには WEBサービスモデルが採用され, WSDL 1.1 (Web Service Description Language) を記述言語として, XMLでエンコ ードされたオブジェクト(CMS(Call Management Server),

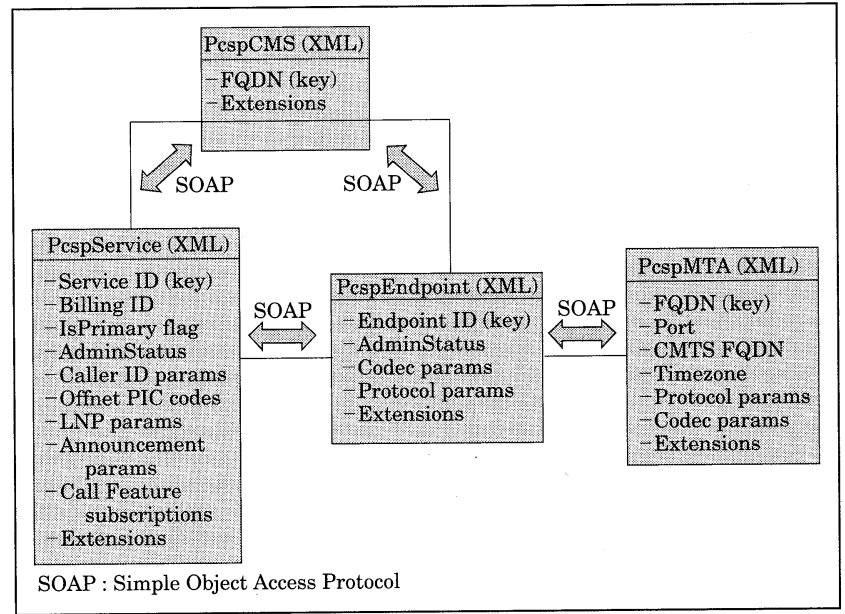

図2 プロビジョニングシステム概要

Service, Endpoint, MTA(Multimedia Terminal Adapter)) 情報をサーバ間に転送するものとなっている。転送用プロ トコルにはSOAP (Simple Object Access Protocol)が採用 されている. 図2にプロビジョニングシステム概要を示す.

サービスオブジェクトにはサービスID, 課金ID, リンギ ングパターン，キャリヤコード等が, MTAオブジェクト にはFQDN (Fully Qualified Domain Name), ポート番号, コーデック種別等が記述されるようになっている.なお, 本仕様の適用範囲は単一サービスオペレータに限定されて いる.

\section{2、ホームネットワーク関連}

ITU-T SG9ではケーブルモデムの上位層を拡張した上 で，各種ポータル機能を組达んでゲートウェイ化し，これ に接続する宅内のネットワークをIP (Non-IPへのプロトコ ル変換含む) で統一するホームネットワークの検討が進め られている.

2.1 レジデンシャル・ゲートウェイ

ITU-Tでは，アクセス網とホームネットワークを接続し， IPパケットレベルで入出力情報をコントロールする機能を レジデンシャルゲートウェイ $(\mathrm{RG})$ と呼ぶ. RGは物理層お よびMAC層としてJ.112またはJ.122ケーブルモデムを持ち, 上位層として，ネットワークマネジメント，プロビジョニ ング，アドレス変換，セキュリティ等の機能を有している. 具体的にはホームネットワークに接続される端末機器との 間でQoSサポート，デバイスとサービスの発見，プラグア ンドプレイ，ファイアウォール，認証，アドレス解決等を 含む広範なインタフェース機能を含んでいる。

(1) ネットワークマネジメント：マネジメントツールと して，管理ポータル，テストポータル，バウンダリ 一(境界) ポイント管理を記述，QoSサポートやデバ イスとサービスの発見もここに記述されている.

(2) プロビジョニング：プロビジョニングッールとして, 
DHCP ポータル, ToD (Time of Day) クライアント, DHCPクライアントを記述.

(3) アドレス変換：アドレスポータルによるW AN側, LAN 側のアドレス変換を記述すると共にDNS によ るネーミング解決も含む.

(4) セキュリティ：機器認証，ファイアウォール，ソフ トウェアダウンロードを記述している.

図3に，ケーブル網におけるホームゲートウェイの概念 を示す.

また，図4に，ポータル機能とWAN側，LAN側インタフ エースの関わりを示した. ケーブル管理ポータル (CMP) の 下にポータルサービス (PS) データベースがあり，各ポータ ル機能と連携を取りながら入出力パケットの処理を行う.

2.2 ホームネットワークアーキテクチャ

ホームネットワークアーキテクチャは基本的には $2.1 て ゙$ 述 ベたRGに接続される各種デバイスの機能クラスと最終的
にサービスを受けるエンドポイント (EP) の接続状況で記 述されている，図5にホームネットワークアーキテクチャ を示す.

図5に示された各種デバイスの機能は以下の通りである.

(1) HA：アクセス網をJ.112またはJ.122ケーブルモデム のRFインタフェースで終端し, 単一ホームネットワ ークまたは複数ホームネットワークとアクセス網を IPレベルで接続, 変換, 処理するデバイスである. このため, 各種ポータル機能を実装している，RGも HAデバイスの一形態である.

(2) HB : 後続する複数バウンダリー (境界) ポイントの接 続と必要に応じてレイヤ変換を行うデバイス.

(3) HC：バウンダリー (境界) ポイント (BP) デバイスで あり，IP-Non IPプロトコル変換の機能を持つ。また， 配下のデバイスのディレクトリ管理を行う．基本的 に一つのBPは一つのプレーン (同一サービスカテゴ

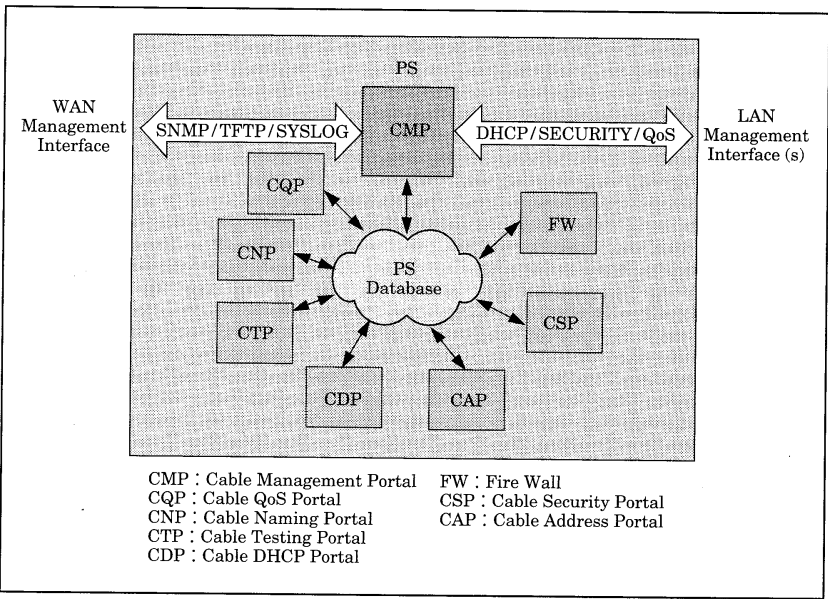

図4 ポータル機能とWAN側，LAN側インタフェース

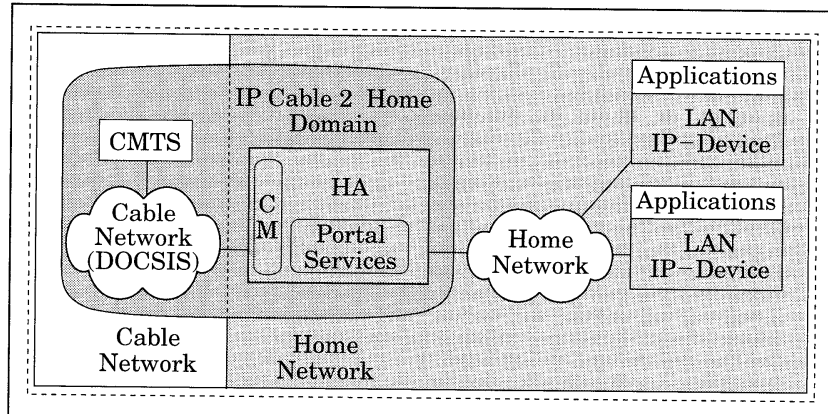

図 3 ホームゲートウェイの概念

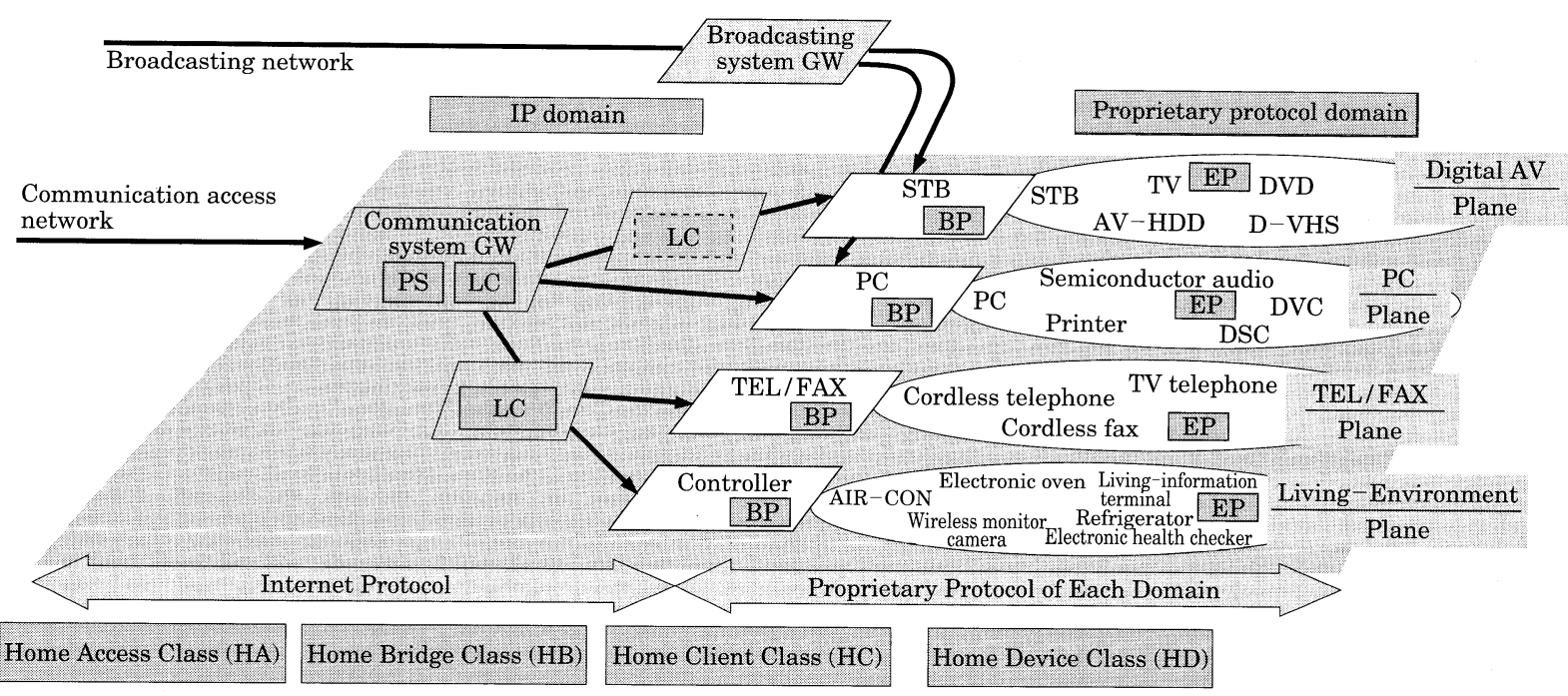

図 5 ホームネットワークアーキテクチャ 


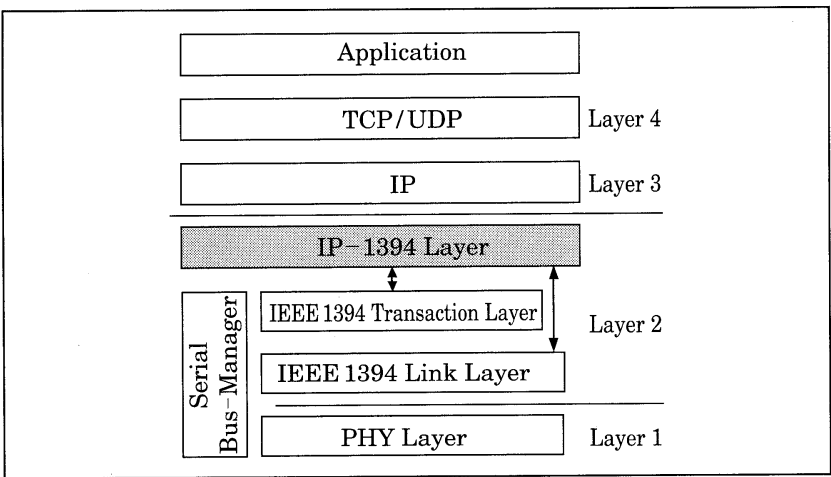

図6 IP over IEEE 1394を含むプロトコル構成

リー)に接続される.

(4) HD：エンドポイント (EP) デバイスの総称であり, 最終的にサービスを受け渡しするデバイスを意味す る.ホームネットワークへの接続には認証機能が要 求される.

\subsection{IP over IEEE 1394}

実際のホームネットワークの構築に当たってはさまざま なトランスポート技術を許容しなければならない．物理層 ではメタリック系，無線系，オプティカル系等が想定され るが，その上位層プロトコルでは，通信サービスではIP， 放送サービスではIEEE1394による伝送が適していると考 えられる。将来の放送・通信融合サービスではIP層の直近 でのプロトコル変換が処理時間的にも有利と思われる．IP over 1394はIEEE1394のリンク，トランザクションレイヤ を利用してIPパケットの送受信機能を提供するもので, IEEE1394の非同期パケット（Asynchronous Packet）を使用 してユニキャストのIPパケットを転送し，非同期ストリー ム (Asynchronous Stream) を使ってブロードキャスト，ま たはマルチキャスト方式でIPパケットの転送を行う。図6に IP over IEEE 1394を含むプロトコル構成を示す.

しかしながら，イーサネット(802系) のネットワークと 1394ネットワークではアドレス体系が異なっている。具体 的には，802系が6バイトの物理アドレスで端末を識別して いるのに対して，1394では8バイトのGUID (Global Unique ID）で端末を識別している．そのため，1394側の端末は802 系ネットワークに接続された端末宛に，逆に802系ネット ワークに接続された端末は1394側の端末宛に直接ユニキャ ストパケットを送信することはできない．このためIP over IEEE1394では, 代理ARP (Address Resolution Protocol）の手法を導入している，代理ARPとは，異なる 種類のネットワーク (1394とEthernet) に跨る端末が, 1394 側に対してはイーサネット側の端末の代理で，イーサネッ 卜側に対しては1394側の端末の代理としてARPパケットを 処理する方法である。この処理により両方に跨る端末は， 1394側には，イーサネット側の任意の端末として，逆にイ 一サネット側には，1394側の任意の端末として擬似的に機
能することが可能になる，本技術によりIP系サービスと IEEE1394系サービスのホームネットワーク上でのシーム レス変換が促進されると期待されている.

\section{3. データ放送API}

2000年12月にBSデジタル放送が開始され，HDTVデジタ ル放送と同時に本格的なデー夕放送が開始された.データ 放送は映像と音声という従来のテレビ放送に対して，文字， 静止画, 別の動画といった要素を加え, 多様な表現を可能 とするマルチメディア放送である。このような情報表現は WWW (World Wide Web) で実現されたものも多い.一方, デー夕放送には番組連動型，独立型のサービスがあり，独 立型サービスではニュースや天気予報といった現在放送さ れている番組とは独立した情報を提供，番組連動型では現 在放送中の番組に関連する情報を提供といった違いがあ る。独立型ではWWWで実現されたものに近い情報表現を とることが多いが，テレビ画面上で実現されるサービスで あり，リモコンで操作されることが大きく異なる。また， 字幕放送との関連制御といった放送特有の処理も行わなけ ればならない，番組連動型では，放送局側からの任意の夕 イミングによる指示に基づくページ遷移などWWWでは実 現されてこなかった技術要素が必要である，例えば，クイ ズ番組での無制限の回答時間などはナンセンスであり，放 送番組の進行に合わせて入力を拒否する等の処理が必要と なってくる。このように，WWWで実現されているものと 似ているようで異なる技術が必要となるのがデー夕放送で ある。

ここでは，このデー夕放送に関する技術的背景および ITUでの標準化について述べていくことにする.

\subsection{PEとEE}

マルチメディアコンテンツを記述する方法として，大別 してPE (Presentation Engine) とEE (Execution Engine) によるものがある。

PEはタグ等を用いてコンテンツを構成する要素 (テキス ト，静止画等）を羅列的に記述するもので，WWWで用い られるHTML (Hyper Text Markup Language) や日本の デー夕放送で用いられているBML (Broadcast Markup Language) ${ }^{1)}$ がこれに属する．羅列的に提示要素を宣言す ることから，宣言型コンテンッフォーマット（Declarative Content Format）とも呼ばれる.夕グで提示要素を羅列し, コンテンツの動き(リモコンによる項目選択やページ遷移 など）はスクリプト言語で記述する．また，レイアウト情 報はCSS (Cascading Style Sheet) ${ }^{2)}$ 等を用いて記述し，そ れぞれの提示要素にレイアウト情報を与える，PEによるコ ンテンツ記述は，シンプルなコンテンツは単純に記述でき， コンテンツ記述は基本的にテキストファイルであるため可 読性に優れるが，複雑な動きや外部機器との通信を行うよ うなコンテンツでは，ブラウザの機能拡張や複雑な記述が
(松本 檀)
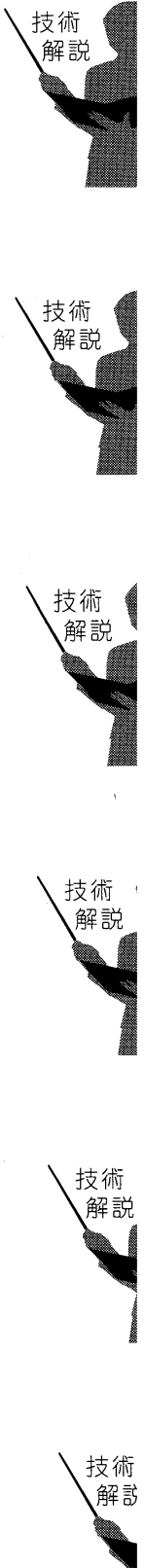

技術

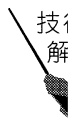

(35) 905 
必要である。

一方EEは, マルチメディアコンテンツそのものをプログ ラムとして記述するものであり，PEのようにコンテンッの 提示要素を単純に羅列する方法は特別な場合を除いて行わ ない*.コンテンツがプログラムそのものであるため, 手 続き型コンテンツフォーマット (Procedural Content Format）とも呼ばれる. 動きの記述そのものがコンテンツ であり, 外部機器との通信や複雑な動きを伴うコンテンツ の記述が比較的容易であり, 受信機に搭載される処理系の 拡張はあまり必要でない。これはPEに比べて一段階低いレ イヤーでコンテンツが記述されるためである，その反面， シンプルなコンテンツを作成する場合にも，それなりの量 のプログラムコードを必要とする.

PEでの体系としては，XHTML 1.0 (HTML 4.0をXML 1.0のシンタックスで整理しなおしたもの) ${ }^{3)}$ をべースとし て, 欧州で開発されたDVB-HTML (Digital Video Broadcasting, Hyper Text Markup Language) ${ }^{4)}$, 米国で 開発されたATSC DASE-1 (Advanced Television System Committee, DTV Application Software Environment-1 $)^{5)}$, ACAP-X (Advanced Common Application PlatformDeclarative) ${ }^{6)}$, SMPTE DDE-1 (Society of Motion Picture and Television Engineers, Declarative Data Essence-1） ${ }^{7)}$ ，日本で開発されたBMLなどがあり，一時期 は乱立の様相を呈していた. しかし, 最近の標準の集約化 などにより落ち着きを見せつつある.

EEとしての体系はOpenTV ${ }^{8)}$ やJavaTV ${ }^{9)}$ などがあるが, DVB-MHP (Digital Video Broadcasting, Multimedia Home Platform) ${ }^{10)}$ が開発されたことにより, Javaをべー スとしたものに集約されつつある.

\subsection{ITU-T J.200}

ITUでは，マルチメディア標準は，CATVと電波を利用 した放送に共通する技術であることから，ITU-T SG9と ITU-R WP 6Mで共同して勧告作成の検討を行っている. このために両組織の間にJRG-1 (Joint Rapporteur Group-1) を結成した。

前述のような技術的背景を踏まえ, まず初めにトータル システムアーキテクチャを記述したアンブレラ勧告を2001 年3月に作成した。これがITU-T J.200である.

J.200においては, PEおよびEEの存在形態，またPEー $\mathrm{EE}$ 間の連携, ネイティブソフトウェア (PEやEEを用いず に記述されるソフトウェア) の存在形態について述べてい る(図7). EEやPEはOSの層の上のシステムライブラリー 層 (ネットワークアクセスやコンディショナルアクセスサ ービス, GUI提示ライブラリー, 放送用イベント・データ アクセスライブラリー等) の上に位置し， EE，PEそれぞれ のエンジンより各ライブラリーにアクセスできるだけでな

* 外部実体（External Entity）としてそのような記述ファイルを持つこと は不可能ではない。

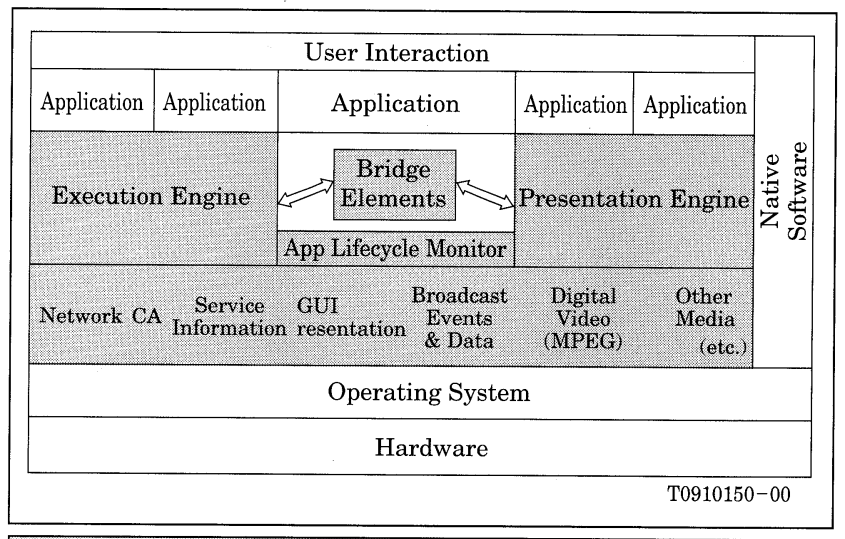

図 7 ITU-T J.200が定めるシステムアーキテクチャ

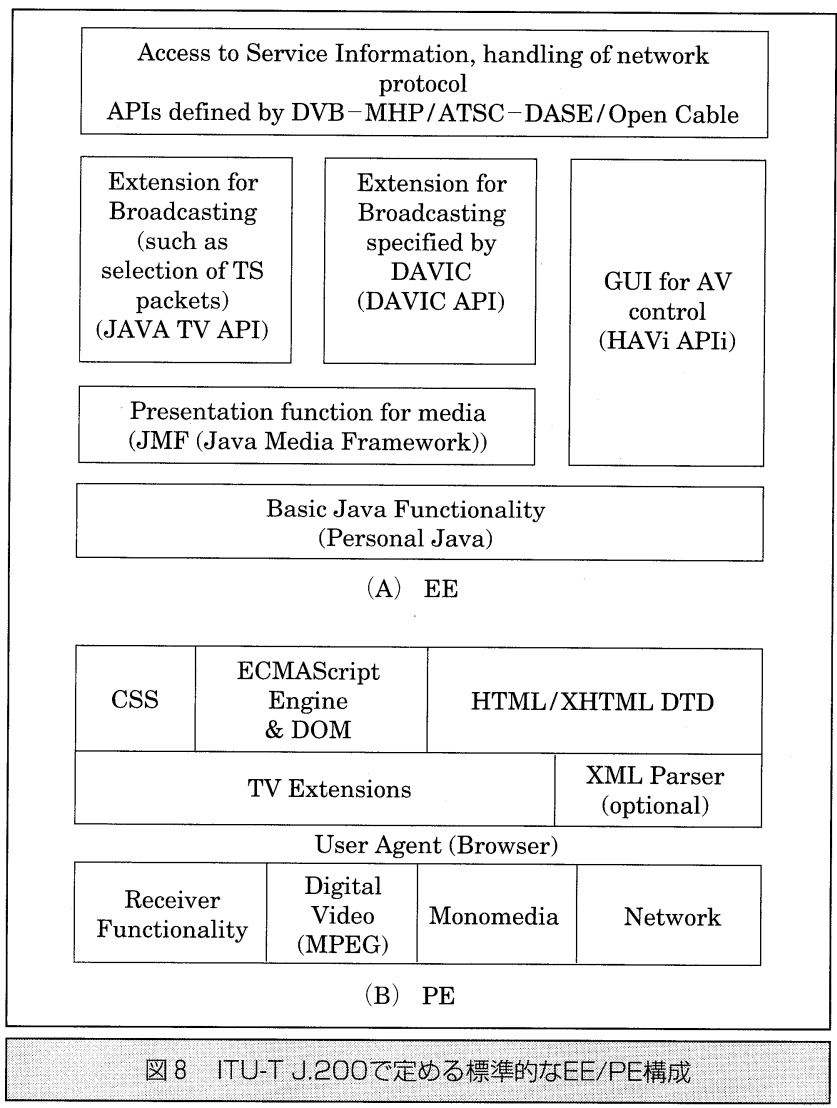

く, $\mathrm{EE}-\mathrm{PE}$ 間のブリッジが存在できることも示している. このブリッジはPEコンテンッ上のスクリプトからのEEメ ソッドの呼び出しだけでなく, EEコンテンッ上からPEコ ンテンツ上のDOM (Document Object Model) ${ }^{11)}$ アクセ なども可能とするものである.

またこの勧告は, 図8に示した様にEEやPEの標準的構成 やベースとなる標準を述べている.

ネイティブソフトウェアは, これら標準の範囲外で存在 するソフトウェア処理系であり, 日本のBSデジタル放送や 地上デジタル放送で言えば, EPG (Electronic Program Guide, 電子番組表) や受信機設定のためのソフトウェアな どが該当する. 


\subsection{ITU-T J.202}

ITU-T J.202はJ.200に次ぐ一連の勧告の一部であり, 2003年4月にEEについて定めたものである.J.200ではEE の標準的構成について述べているものの, その詳細につい ては述べていない，その詳細について規定している钦告が J.202である.

EEについては，DVB-MHPが作成されたことは前述した が，MHP 1.0をべースとして，DVB固有の API (Application Program Interface) を除外し, 各地域におけ る標準化団体が同等な機能を実現すべきものについてまと めたGEM (Globally Executable MHP) 1.0 12) がDVBにおい て作成された。 GEM1.0は，下記の構成となっている。

(1) PersonalJava (コア仮想マシン仕様) ${ }^{13)}$

(2) JavaTV (サービス選択，番組リソース取得等の放送 用拡張API)

(3) JMF (Java Media Framework)（映像・音声等のスト リームアクセス用拡張API) ${ }^{14)}$

(4) DAVIC API (DAVICで拡張されたリモコン用API等) ${ }^{15)}$

(5) HAVi Level 2 UI API (HAViで拡張されたGUI API)

(6) DVB拡張API（DVBで拡張された標準的放送用拡張 API)

（7）最低限必要なモノメディア規定

J.202はGEM 1.0をべースとしており，共通のコアAPIと DVB (MHP1.0および1.1)，OCAP (Open Cable Application Platform，米国のCATVの標準方式） $1.0^{16)}$ ，DASE-1 (DASE-1にはEEの規定も存在する) ${ }^{17)}$ ， 日本のARIB STDB23それぞれにおける追加機能パッケージと英国MHEG-5 をJ.202上で動作させるために必要な修正をまとめたもので ある。

MHP1.0，OCAP1.0，ARIB STD-B23といった標準はい ずれもGEMベースの形で記述でき，これらの標準はITU-T J.202に準拠していると言える.一方，これらの標準でJ.202 に対して拡張している部分は，それぞれの標準化団体が定 めるトランスポートプロトコルに依存する部分や，シグナ リングに依存する部分，固有の使用言語 (日本語や英語な ど）に関する部分であり，それぞれの仕様に基づいて記述 されたコンテンツが直ちに他の処理系において実行可能と なるとは限らないものの, 必要な変更部分は明確であり, 移植そのものは容易となるようになっている，各標準と J.202の関係を図9に示す。

また，GEMはJavaをべースとしており，Javaそれ自身は 高い記述性を持つ，優れたオブジェクト指向言語という側 面も持っていることから，EE上でPEコンテンッを実行す るためのブラウザを記述することも可能である．この場合， PEコンテンツに併せてそれを実行する処理系であるブラウ ザも放送波に乗せ，最初にブラウザを実行開始し，ブラウ ザにPEコンテンツを読み込ませて提示する，PEベースで 開始したサービスをEEベースへ移行したり，EEとPEを併

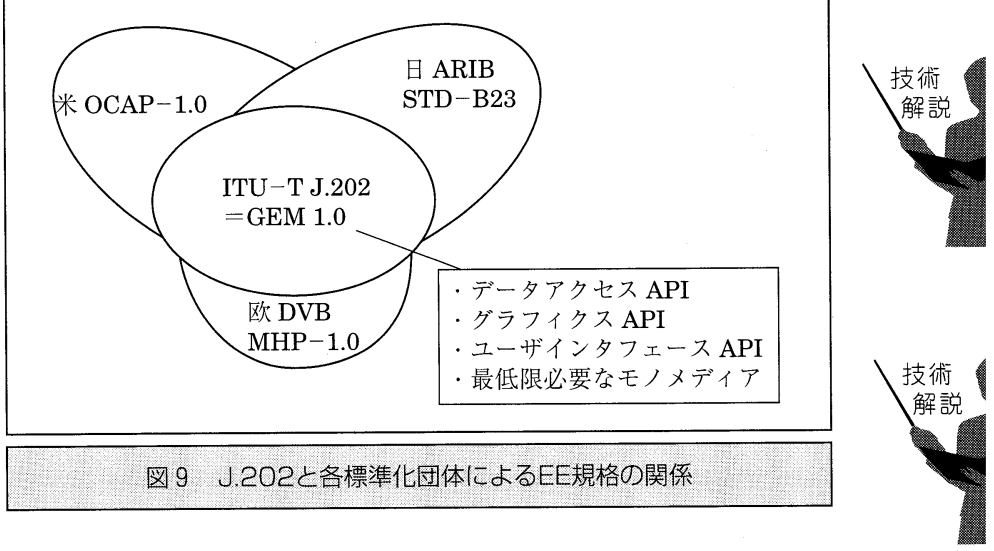

用する時などは有効な方法である。

\subsection{PE勧告案}

J.202に続いてPE標準に関する针告案もITUでは検討され ている．基本的にJ.200のアーキテクチャに基づいた勧告と なる方向である。前述の通り，一時期の乱立の様相はおさ まりを見せつつあることから，各標準化団体で規定するPE 仕様の共通部を規定する锥告が作成できる可能性がある. 3.1節で述べたPE仕様はどれも，XHTMLを記述の骨格と し，提示制御のスタイルシートとしてCSS，XMLで記述さ れた要素にアクセスするためのインタフェースとして DOM，スクリプト言語としてECMAScript ${ }^{18)}$ を使うとい う点では同じである。これらを組合せて，EEと同様， (1) 映像・音声のストリームアクセス, (2)リモコンによる入力, (3)放送局側からのイベント信号処理などの機能拡張が図ら れている. BMLでは, さらに外部機器へのメッセージング, プリンタへのアクセス, 受信機に内蔵された記憶装置への 入出力などの機能が実現されている.

しかし，DVB-HTMLやACAP-XのようにEEの存在が前 提となるPE仕様であったり，一方でBMLのように独立し て機能するものであったりなど，本質的な構成が異なるも のもあり，勧告はEEの場合と同様，共通部とそれぞれの 仕様が独自に追加した部分を区分するものとなる。

ただし，世界的には現時点ではEEを用いたサービス展開 がようやく始まろうとしているところであるが，すでにサ ービスを開始した日本のように，PEベースで展開している ところは少ないため，予断は許さない。

\section{5 今後の動向}

図10は，各地域でのマルチメディア放送システムの採用 状況である. 現在ITU-Tでは, アンブレラ勧告とEE勧告が 作成されているものの, 英国と日本で実際に使われている PEの勧告がなく，また，無線放送を所掌するITU-Rで関連 勧告が作成されていない。したがって，今後ITU-Rでの勧 告化も必要である.

さらに，ITU-Rでは無線放送を対象にした勧告となるの で，ITU-Tでは範囲外となる携帯・移動端末向けの仕様も 対象となる。したがって，こういった状況を併せて勧告化 作業を進めていくことが，デー夕放送コンテンツの国際交 
